\section{ECONOMICS

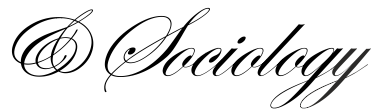

\author{
Agota Giedrè Raišienè \\ Faculty of Politics and \\ Management, \\ Mykolas Romeris University, \\ Vilnius, Lithuania, \\ E-mails:agotar@mruni.eu; \\ agotagiedre@gmail.com
}

Received: April, 2014

1st Revision: June, 2014

Accepted: September, 2014

DOI: $10.14254 / 2071-$

789X.2014/7-3/14
Raišiené, A. G. (2014), Leadership and Managerial Competences in a Contemporary Organization from the Standpoint of Business Executives, Economics and Sociology, Vol. 7, No 3, pp. 179-193. DOI: 10.14254/2071789X.2014/7-3/14

\title{
LEADERSHIP AND MANAGERIAL COMPETENCES IN A CONTEMPORARY ORGANIZATION FROM THE STANDPOINT OF BUSINESS EXECUTIVES
}

\begin{abstract}
The aim of the article is to present the insights of advanced organization management and to examine how settled ideas are reflected in the attitude of organizations' top management in Lithuania. The results of meta-analysis revealed that modern organizations should be managed with a new attitude to manager's work. A modern manager must be a leader who is able to enable employees and collaborate in a team. Scholars state that these strivings require the leader to possess managerial competences based on a high emotional and social intellect of a person. Leaders of 48 empirically examined organizations in Lithuania also emphasized the importance of leaders' specific managerial competences. The research participants noted that relations with other people are becoming much more important for the contemporary leaders than before.

The research enabled to develop a model of modern leader's characteristics. The model states that only leader having specific values, attitudes, competences, abilities and professional characteristics is able to overcome managerial challenges in nowadays organizations.
\end{abstract}

JEL Classification: L20, M1, M12

Keywords: leadership, managerial competences, organization management.

\section{Introduction}

Organization success is inseparable from the managerial practice just like any organized social activity is inseparable from the values, attitudes, abilities and behaviour of the group's leader. Practical problems of management and leadership are being solved for as much as mankind exists. However, question of management efficiency and leadership effectiveness are still relevant. The cause of this is the fact that social, along with economic and technological environment is changing. Due to this reason challenges and assignments of organization management are changing as well. Thus each manager should renew his attitudes, managerial skills and behavior by requirements of current date.

Leadership is extraordinary because a one-direction arrow cannot be drawn trying to show leader's and the organization's interdependency. It is myth to believe that leaders, who 
only consider the requirements of market and the society are exactly what organizations pursuing efficiency need. The organization's dependence on its leaders is much more broader. In addition, formal and informal leaders of the organizations influence not only the work specifics and success of organizations they are working in, but also form business environment, partner organization's communication style and even indirectly influence the market needs by forming the client's comprehension on what they could wish for and what is possible and acceptable in general. In other words, not only the environment changes motivate organizations and their leaders to change, but also leaders affect the medium of existence of the organization and inspire changes in its environment.

The factor of management is also important when considering the inward of the organization. As Thompson (2010) notices, the leaders' influence in the organization is felt in various activities, from creation of work strategy of the whole company and work planning to communication features of separate group's members in a project. Therefore, a particular attention has to be given to the organization managers and the development of their leadership competences in order to reach good results, because leadership is the axis that kick-starts all other processes in the organization and affects numerous variables outside the organization. The insights on managers' competences should be grounded with proofs and arguments. This may be achieved by investigations, by knowledge gathered on research conclusions, and by conversance in real managerial problems.

In this context, the aim of the article is to define insights of advanced management by using meta-analysis, and to examine how settled ideas are reflected in the attitude of organizations' top management. Three assignments were set in order to achieve the aim: 1) to carry out an analysis of modern scientific publications and to highlight the organization leaders' competences that are mostly required by the current time; 2 ) to carry out a qualitative research in order to ascertain, what managerial and leadership competences does the organizations' top management name as the most important in modern organizations; 3) to compress the results of meta-analysis and interviews by submitting a schematized portrait of a modern organizational leader, i.e. to propose a model of leader's values, attitudes and abilities he needs in any contemporary organization. The methods of the research were meta-analysis, interview, and content analysis.

The article is composed of four parts. The first part reviews the newest attitudes to leadership, the second one examines the question of modern organization leader's competences. In the third part, results from 48 interviews with organization leaders are presented. The fourth part compares the results of theoretical analysis and empirical research and presents a model of modern leader's values, attitudes and abilities. Summarized conclusions are given in the end.

\section{Leadership in contemporary organization management}

The modern conception of leadership emphasizes not only the leader as an individual, but also the group he influences and joint results, which often determine particular changes in the internal and external environment of the organization. Leadership is a set of functions that cover at least three variables: the leader, his followers and the conditions dictated by the situation. Leadership is a plethora of combinations formed by these variables (Bahreinian et al., 2012, p. 101). As Drodge and Murphy (2002) notice, management is considered as a rational social activity, when a formal leader concentrates his effort to achieve organizational goals. A manager acts according to determined responsibility and procedures, and does not actually create something new in contrary to leader, who forms assignments and seeks for innovation (Diska, 2009, p. 16). Moreover, the current researches show that boundaries between government, management and leadership blurred (e.g. Belak, Duh, 2012). Of course, 
strategic and political skills of formal leaders have not lost their importance. However, the management (formal leadership) in itself does not determine the organization's success anymore (Goulding, Walton, Stephens, 2012). In the recent decade, is seen that management cannot be isolated from the context in which managers work. Thus, managerial success is more influenced by specific personal characteristics and leadership skills which manager develops purposefully on his own (Wijepala, Wijesundara, 2011) and by his entrepreneurial characteristics that are revealed by working in both macro and micro levels of the organization (Jinadasa et al., 2011).

After an analysis of results gathered by wide scientific publications it is obvious that traditional leadership is becoming less effective in comparison to the followership. The leaders' ability to control relations without creating organizational and moral dilemma is emphasized by a majority of modern management researchers. According to Keast and Mandell (2011), leaders need to understand the inseparability of their employees and themselves: leaders cannot realize the goals of their subdivision or organization without the help of their employees. Thus traditional methods of management (giving orders and monitoring) are not actually working effectively anymore, due to specialists being equal in qualification and competences to the managers. Now, only collaboration matter.

This was also noticed by Iqbal (2012). He divided the schools of modern managerial thought into two types. Theories which state that formal leader's purpose is to control employees were attributed to the first type. These theories are based on the conventional attitude to leadership. The second type contains theories that are based on the new attitude. These theories regard the provision that people wish to do something meaningful and beneficial, and the leader has to motivate them by setting joint goals and encouraging to accomplish assignments. This new paradigm could be called the paradigm of collaborative leadership.

Conceptually, collaborative leadership could be described as a join creative process that takes part in a joint environment (Vizgirdaite, 2011). Collaborative leader is oriented to the team success, creation of friendly atmosphere and adjustment the interests of group members with organizational goals. Latter-day leader has to be able to envisage the best skills of a particular employee and apply them in difficult situations during decision making (Linley et al., 2009). In addition, leader would be able to inspire the work group for high achievements and responsibility for decisions and for results (DeRue et al., 2010).

The methodological aspects of collaborative leadership paradigm are widely examined in various directions or sub-tipes, such as facilitative leadership, servant leadership, coaching and supportive leadership for example. Speaking about the sub-types of collaborative leadership it may be observed that all of them have a horizontal relation: leader is collegially asking the employee's opinion on how to cope with a particular assignment and what goal would be appropriate to set in the given situation (Raisiene, 2014).

The idea of servant leadership was developed by Greenleaf (1996), who stated that the hierarchical gap between leaders and employees is not beneficial for the organization. Servant leadership covers the majority of important leader's skills. Thompson (2010, p. 112) names the following: listening, empathy, healing and maintaining relationships, consciousness, persuasion, conceptualization, insightfulness, leadership, commitment to people's growth and creation of a community. In his research, Jones (2011) revealed that servant leader is extremely positively evaluated by the employees, according to them it is very beneficial for pursuing organizational goals.

The facilitative leadership theory argues that leaders should create a suitable environment for collaboration as well as for organization goals' implementation. As state Žukauskaitė (2010) and Kiaunytė\&Večkienè, (2011), facilitative leader behaves with consideration to the employees' personal needs and seeks to help employees solve problems. Also, he motivates them to work and independently, and in the team. 
Observing the couching it could be noticed that a coacher is learning from and with the group members (Misiukonis, 2013). This leader is certain that employees by themselves have the knowledge about what should be done and how it should be done to implement the organization goals.

Supportive leadership is also attributed to the paradigm of collaborative leadership. Supportive leadership is defined as "support to the efforts and behaviour of the followers when the leader states that he respects his followers and considers their feelings and needs" (Naqvi et al., 2011, p. 40). Such individual attitude to each and every member of the organization makes the leader a main object of trust and support and motivates the followers to work more effectively and reach the needed results.

Therefore, in a context of modern attitude to leadership, management in organizations should be defined as the creation of stable and trust-based relationships with the stakeholders inside and outside of organization and coordination of action in order to reach joint goals. As Laužikas \& Mokšeckienè (2013) states, employees' entrepreneurship is directly related to leadership skills in generating and executing innovative ideas, necessary initiatives and efforts. As can be seen nowadays, awareness on leadership and management widened, and leadership models based on holistic attitude were created. That changes reveal the necessity of new competences of formal leader (e.g. Quatro et al., 2007). The search for effective models of leaders' conditioning and programs of managerial skill development become especially important.

Based on their research, Marquis and Huston (2009) prognosticate the competencies that the future leaders in organizations will require:

- Deep knowledge and a global attitude to one's work area.

- Technological skills that ensure mobility in the contexts of personal relationships, group interactions and processes.

- Expert skills in decision making.

- Ability to create organizational culture that would ensure a universal security of both the client and the employee.

- Ability to understand and influence the political processes of the organization.

- Ability to coordinate personal authenticity (individuality) and the expectations of organization and employees with regard to the leader's personal characteristics.

- Ability to create a vision and inspire the employees in an environment of continuous changes.

In addition, the majority of researchers state that a modern leader must characterize with high emotional and social intellect. Emotions play an important role in life: due to differences in emotional intellect people differ in their ability to accept, understand, use and control emotions. These differences have influence on the individual's ability to adapt in various situations, including the work environment (Cherniss, 2010). A research carried out by Guillen L. and Florent-Treacy E. (2011) shows that leader's emotional intellect has a big influence on the collaboration of the team, while the leader's ability to work in a team is in a way a connecting link between emotional intellect and commanding leadership style.

In the year 2009, a wide scale research was carried out on the expression of leaders intelligent competences in Lithuanian companies which showed that emotional and social intellect is especially important for leaders in the modern business (Skaržauskienè, Paražinskaite, 2010). Therefore, the leader's emotional intelligence and social competences are effective tools of leadership. The leader's social intelligence have a direct influence on his ability to affect employees. In this way, he uses his advantage of social intelligent and is able to increase the satisfaction of his subordinates, which in turn allows to go in a wished direction, achieve the set goals and increase the efficiency of the team. Development of social competences may have influence on better relations with clients, including higher clients ${ }^{6}$ 
satisfaction and higher probability of business growth. Neale (2010) notices that interpersonal relations is a connection that is created by sincerity, understanding and respect to others.

In conclusion, it could be said that collaborative leadership is impossible without leaders that characterize in high social competences. According to Izdonaitè-Medziunienè I, Medziunas R. (2008), social competences that motivate collaboration can be divided into these categories of skills:

- Collaboration (e.g.. involvement into work, skills of negotiation, contracting, teaching);

- Management (e.g. management of time, resources, conflicts, self-control, stress, competition, risk, anxiety);

- Skills of interpersonal relations (e.g. leadership, support to others, self-esteem, empathy, self-realization, understanding, active listening, emotional insight);

- Training/teaching and creativity (e.g. professional training, general training, development of performance, development of creativity).

During the analysis of scientific publications on leadership and managerial competences, it can be noticed that authors give more attention to the leaders' roles, behaviour and personal characteristics, while only a small part invite to regard demographical and geographical factors, influence of different cultures (e.g. Bahreinian et al., 2012) that also have a considerable influence on the practice of management. As set of researches show, people in different countries differently evaluate the characteristics of effective leadership and features of a successful manager, despite the fact that all of them agree that the leader's influence is unquestionable. Bhatti et al. (2012) states that one may never be ensured that one or another type of leader's behaviour will bring effective results; though it is unquestionable that any behaviour of the leader that is used for work organization will strongly influence the results, whether it would be positive or negative influence (p. 750). As a result, the adaptability of leaders' managerial skills should be emphasized as a critical factor of organization's success. Leaders either show or do not show an inspiring example to their employees in turn expressing a vision and emphasizing the collective identity, expressing trust, spreading optimism, indicating the main values and objectives (Grant, 2012). Herewith, it should be highlighted that the personal characteristics, knowledge, abilities and skills are not enough for the leader to be actually competent. By words of Gordon et al. (2012), the manager may have a lot of knowledge, but be unable to adequately work in one or another situation. Due to this reason, competent leaders are distinguished from the incompetent not by their knowledge, but by their ability to effectively use this knowledge in unknown situations, as well as the ability to effectively work in a long-term perspective.

\section{Characteristics and competences of managers as seen by business executives in Lithuania}

Theoretical analysis has made clear that in the modern organizations, manager's and leader's roles merged and researchers hold collaboration skills the most important competence of managers and leaders. Collaboration skills essentially cover the ability to inspire and rally the employees to pursue a join goal, effectively communicate, and help to solve risen problems. In order to accomplish this, leaders have to characterize in high emotional and social intellect. However, it should be noticed that a minority of publications regards the conclusions of good experience analyses. The researchers more often determine the problems and form recommendations only based on insights that could allow to change the situation in a wanted direction. The question remains unanswered, how the leaders of modern organizations 
themselves comprehend the challenges of current leadership and what characteristics and managerial competences they actually consider important, in the context of organizations " efficiency and sustainability. It is purposeful to widely examine this problem and compare results, regarding cultural aspect. In this way, general changes influenced by the values, attitudes and managerial skills of a time could be identified. This would allow both organizational leaders and professionals of competence development to work with considerably more efficiency, without wasting time on issues that are less relevant during that time.

The goal of empirical research was to determine the most important managerial competences required in the modern organizations. For this purpose, 48 leaders of Lithuanian organizations were questioned.

\subsection{Research methodology}

48 small and medium sized enterprises from facility and service sector, registered in the city of Vilnius, were chosen for the survey. A non-stochastic sample was chosen. The criteria of the selection were the length of company's existence and area of activity. We made an assumption that if a company exists in the market for no less than 10 years, its leaders apply effective models of business management and their opinion on what is the most important in a leader's work can be treated as expert.

We chose organizations from facility and service sector because the work specifics of these companies require considerable self-reliance from employees, so directive - traditional - methods of management should not be effective. Of course, this influenced the limitation of the research, because the conclusions of the research can only be generalized on a scale of the facility and service sector organizations.

A structured interview method was applied for the survey. The leaders of all 48 companies were interviewed. There were no flawed interviews which should be rejected. During the interview, a record was being made that we later transcribed. Every interview were from 15 to 30 minutes in length. Total duration of interview records is 1008 minutes. Generalized data of the interviews are presented in the tables.

During the interview, we asked the company leaders to share their opinion on which characteristics of a leader are the most important, comparing the current time with previous one and which managerial competences are necessary in order for the organization to successfully overcome the challenges of a time. We also asked what leadership functions, in their opinion, are the most important and what is important when organizing the realization of employees $^{6}$ assignments. Finally, we asked to indicate, which management style: directive, democratic, liberal, transactional, transformational, situational, collaborative, serving, developing or supportive - allows to reach the best results and which one of them is most often applied by the leaders of the represented organization. We defined each term briefly and purposefully included choices as various as possible.

\subsection{Results of the interviews}

We started the interview with a request to share the opinion on which leader's characteristics are the most important, comparing this time with the earlier. It is important to note that none of the questioned were surprised by the question and no one stated that they do not notice changes. The most often mentioned characteristics were as follows:

1) initiative and activity (mentioned by 44 out of 48 respondents),

2) determination (mentioned by 42 out of 48 respondents),

3) attention to the employees' needs (mentioned by 41 out of 48 respondents),

4) responsibility (mentioned by 38 out of 48 respondents), 
5) dedication to work (mentioned by 37 out of 48 respondents),

6) frankness (mentioned by 32 out of 48 respondents),

7) emotional balance (mentioned by 31 out of 48 respondents),

8) practicality (mentioned by 26 out of 48 respondents),

9) attentiveness (mentioned by 22 out of 48 respondents),

10) flexibility (mentioned by 20 out of 48 respondents).

The analyzed data of the interview show that a part of the mentioned characteristics can be attributed to the personal characteristics of the leader himself, i.e. they are directed to the leader himself. However, a similar part of the indicated characteristics are related to social competences, suitability for interpersonal interaction. Table 1 defines these characteristics in detail.

Table 1. Professional characteristics of a modern leader according to the participants of the research

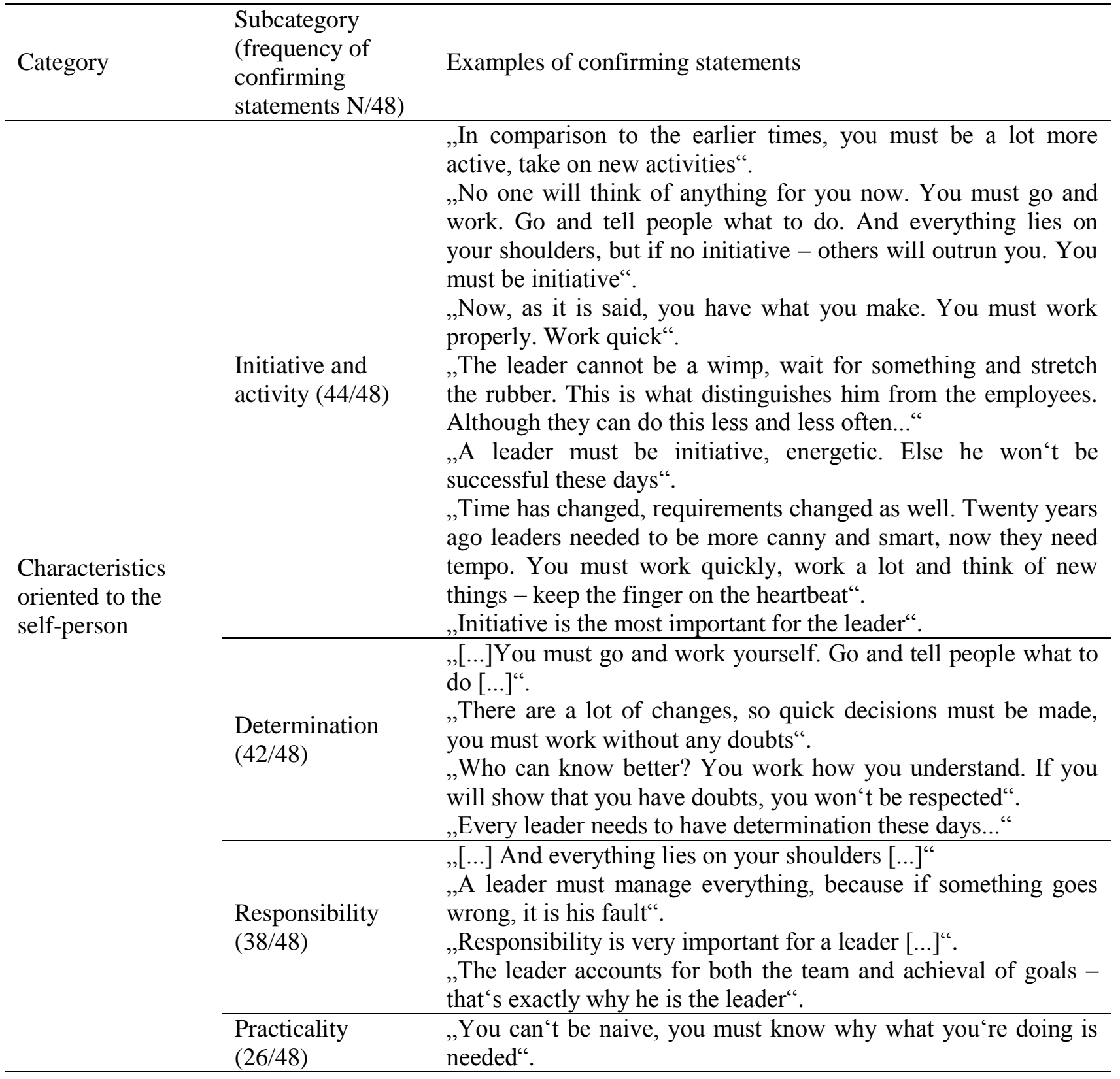


„You must calculate what you invest and what you get".

"It is simply beneficial for the leader to respect employees".

,$[\ldots]$ how he will behave, his employees will behave. If not with him, then with each other. Therefore, not every behaviour is beneficial“".

„Problems must be solved in a clever way. The leader evaluates if the decision is good and will it pay off. You simply have to be practical“.

„Everything is changing, and it should be regarded“.

"You should not worry that the „hat will fall off" - the

Flexibility (20/48) employees are competent, you must adapt to their tempo and attitude and the change it step-by-step“".

„Negotiation, smart and honest at the same time - this is what modern leaders need".

"You should not worry that the "hat will fall off" - the employees are competent, you must adapt to their tempo and attitude and the change it step-by-step".

Attention to the employees' needs $(41 / 48)$

„You must respect employees, because without them, the leader is nothing".

„Everyone are well educated these days, so today you're a leader and tomorrow the leader is your employee. It is unworthy to ruin relations. Mutual respect is the most important".

„The leader cannot think he is a God. Attentiveness, respect and listening is important".

\section{„Workaholics are successful now“.}

„One that works without counting hours achieves a lot and the

Dedication to the company flourishes".

work (37/48)

„Leaders must care about the company. There is an abundance of such mere hirelings, but a good leader loves the company as his own".

Characteristics oriented to other people
„It is important that the employees understand you“.

"It is bad if one lies..."

Frankness (32/48) „It seems that frankness, honesty and mutual respect is out of fashion, but I think oppositively - it came to fashion significantly“.

„The leader cannot allow himself to yell“.

„If you will yell frothed, you will only ruin your reputation and nothing else. You won't achieve anything with such behaviour".

Emotional balance, control $(31 / 48)$ smile..."

„Emotional balance is very important for the leaders $[\ldots]$ ]“

"Emotions should be shown, but you must know how..."

"The leader shows and example. The way how he behaves is the way how his employees will. This means that not every behaviour is beneficial".

„The leader cannot think he is a God. Attentiveness, respect and listening is important".

Attentiveness and ability to listen $(22 / 48)$
„Leader's attentive listening and attentiveness is what drives the employees these days".

„The leader must be acute, quickly catch what employees want to tell him. He must know how to ,read between the lines“.

Source: author's compilation based on the research results. 
We also asked the participants of the research what abilities does a modern leader need in Lithuania in order for his company to be successful. The questioned leaders of the organizations mentioned numerous various points, however, five most important ones emerged:

1) ability to communicate,

2) ability to make decisions in a team,

3) ability to collaborate,

4) ability to help the employees to achieve a result,

5) ability to overcome various contradictions.

It may be noticed that the mentioned abilities are especially related with two aspects of intellect thanks to which high managerial competences are formed: 1) emotional intellect (according to Stys, Brown (2004), it essentially covers self-image, adequate comprehension of others and management of interpersonal relations) and 2) social competence, i.e. the ability to effectively communicate with other people. The generalized results of the research are presented in Table 2.

Table 2. Abilities of modern leaders necessary in order to successfully lead an organization

\begin{tabular}{|c|c|c|}
\hline Category & Subcategory & Examples of confirming statements \\
\hline \multirow{4}{*}{$\begin{array}{l}\text { Ability to } \\
\text { communicate }\end{array}$} & $\begin{array}{l}\text { Effectively } \\
\text { form } \\
\text { assignments }\end{array}$ & $\begin{array}{l}\text { "If a leader has to repeat two times what to do, it does not mean } \\
\text { that the employee does not understand, it means that the leader is } \\
\text { not able to speak clearly“. } \\
\text { "A competent leader must firstly be able to communicate and put } \\
\text { thoughts in a way that everyone would know what is important". }\end{array}$ \\
\hline & $\begin{array}{l}\text { Ventilate one's } \\
\text { attitude }\end{array}$ & $\begin{array}{l}\text { "Threats and intimidation are outdated. Nowadays you must } \\
\text { explain how you see something until the employee understands } \\
\text { what position you are holding“. } \\
\text { „When a leader speaks, it must be clear what he thinks about it“. }\end{array}$ \\
\hline & $\begin{array}{l}\text { Listen and get } \\
\text { feedback }\end{array}$ & $\begin{array}{l}\text { "Communication isn"t effective without feedback. And this, in } \\
\text { fact, mostly works in practice“. } \\
\text { "When communicating, the leader must be able to hear what is } \\
\text { said by the employees and return what he heard so that people } \\
\text { would know how they look from aside and could correct their } \\
\text { decisions themselves". }\end{array}$ \\
\hline & $\begin{array}{l}\text { Organize } \\
\text { discussion and } \\
\text { manage a } \\
\text { dialogue } \\
\end{array}$ & $\begin{array}{l}\text { "A leader works with people, which means that the most } \\
\text { important for him is to effectively communicate with the group“. } \\
\text { "Pointless, useless meetings are the biggest problem. The leader } \\
\text { must be able to manage a meeting“. }\end{array}$ \\
\hline \multirow[b]{2}{*}{$\begin{array}{l}\text { Ability to make } \\
\text { decisions in a } \\
\text { team }\end{array}$} & $\begin{array}{l}\text { Delegate } \\
\text { assignments }\end{array}$ & $\begin{array}{l}\text { "If a leader still wants to make decisions on his own - he is an } \\
\text { outdated leader“. } \\
\text { "A leader must show the direction, say what is the goal, but } \\
\text { people themselves must make everyday decisions, a leader } \\
\text { should not intervene them“. }\end{array}$ \\
\hline & $\begin{array}{l}\text { Consider the } \\
\text { notes and } \\
\text { requests of the } \\
\text { employees }\end{array}$ & $\begin{array}{l}\text { "You cannot do everything like the leader wants. Without } \\
\text { people's involvement they will quickly become unmotivated and } \\
\text { uninterested in realizing unilateral decisions". } \\
\text { "Employees can help the leader a lot, because they are very } \\
\text { qualified nowadays. If a leader does not pay attention to the } \\
\text { remarks of any of them, he can work in the organization alone“. } \\
\text { "It is important to ask for opinion when making decisions, } \\
\text { respect wishes. However, it must be oriented to the result. Then } \\
\text { the employees will want to pursue [organizational] goals“. }\end{array}$ \\
\hline
\end{tabular}




\begin{tabular}{|c|c|c|}
\hline & Manage time & $\begin{array}{l}\text { "A leader works in a team. He must dedicate time for the team, } \\
\text { but also not to overdo when making decisions - time is too } \\
\text { valuable“. }\end{array}$ \\
\hline \multirow{4}{*}{$\begin{array}{l}\text { Ability to } \\
\text { collaborate }\end{array}$} & $\begin{array}{l}\text { See the totality } \\
\text { and effectively } \\
\text { coordinate work }\end{array}$ & $\begin{array}{l}\text { „He [the leader] is together with everyone, but he still needs to } \\
\text { see and control everything himself“. } \\
\text { "A leader mostly maintains relations and coordinates } \\
\text { assignments. Such leader is successful in collaboration and at the } \\
\text { same time „busting out a result". }\end{array}$ \\
\hline & $\begin{array}{l}\text { Decrease } \\
\text { interpersonal } \\
\text { competition }\end{array}$ & $\begin{array}{l}\text { "If you're collaborating, you're not competing..." } \\
\text { "Sometimes employees fight until they do not understand that } \\
\text { they're working together anymore, they cannot complete the } \\
\text { project alone. The leader is the person who must be able to pet } \\
\text { everyone so that no one thinks he is better than another". }\end{array}$ \\
\hline & $\begin{array}{l}\text { Motivate } \\
\text { concentration } \\
\text { and form a } \\
\text { community }\end{array}$ & $\begin{array}{l}\text { „A leader is only the person who composes a united fist out of a } \\
\text { team“. } \\
\text { „Projects best show that „all for one and one for all“ is certainly } \\
\text { necessary. The leader is exactly who plays D“Artagnan for his } \\
\text { employees“. }\end{array}$ \\
\hline & $\begin{array}{l}\text { Strengthen } \\
\text { interpersonal } \\
\text { trust }\end{array}$ & $\begin{array}{l}\text { "Collaboration is inseparable from trust. I did read this not so } \\
\text { long ago, but it is exactly what I think myself“. } \\
\text { "Trust is very important. We will not work together if we do not } \\
\text { trust each other. This firstly derives from the leader himself“. }\end{array}$ \\
\hline \multirow{3}{*}{$\begin{array}{l}\text { Ability to help } \\
\text { the employees } \\
\text { achieve a result }\end{array}$} & Inspire for work & $\begin{array}{l}\text { „If they want, they work perfectly. It is the leader's job to make } \\
\text { them want it. Really want it, not only [pursue] money“. } \\
\text { „It is important to ask for opinion when making decisions, } \\
\text { respect wishes. However, it must be oriented to the result. Then } \\
\text { the employees will want to pursue [organizational] goals“. }\end{array}$ \\
\hline & $\begin{array}{l}\text { Motivate } \\
\text { personal } \\
\text { responsibility }\end{array}$ & $\begin{array}{l}\text { "You clearly tell what and how, and further, well, you just trust } \\
\text { them. You intervene only if something is needed“. }\end{array}$ \\
\hline & $\begin{array}{l}\text { Supply the } \\
\text { needed } \\
\text { resources }\end{array}$ & $\begin{array}{l}\text { "The leader must be able to work not only in the market, but in } \\
\text { his organization as well". } \\
\text { "What do you mean what if there"s no money?! Then there is no } \\
\text { work. People are able to adapt, but it is very costly for the } \\
\text { organization". } \\
\text { "If they say something is needed, sit down, listen and make sure } \\
\text { they have everything for the job to be done". }\end{array}$ \\
\hline \multirow[t]{2}{*}{$\begin{array}{l}\text { Ability to } \\
\text { overcome } \\
\text { various } \\
\text { contradictions }\end{array}$} & $\begin{array}{l}\text { Control } \\
\text { conflicts and } \\
\text { arguments }\end{array}$ & $\begin{array}{l}\text { "There is always friction. And it should be. Though it is } \\
\text { important that it would not grow into something insoluble“. } \\
\text { "Women are not bigger harpies than men. They simply cannot } \\
\text { stand when they don"t understand which side the leader supports. } \\
\text { They intrigues start. A leader must be very insightful and know } \\
\text { some techniques to soothe conflicts. Then everything is fine“. } \\
\text { "Truth is born in conflicts. It is very good when different } \\
\text { opinions are expressed. However, of course, a leader must work } \\
\text { very professionally in this case“. }\end{array}$ \\
\hline & $\begin{array}{l}\text { Mitigate } \\
\text { excessive } \\
\text { competition }\end{array}$ & $\begin{array}{l}\text { "Sometimes employees fight until they do not understand that } \\
\text { they're working together anymore, they cannot complete the } \\
\text { project alone. The leader is the person who must be able to pet } \\
\text { everyone so that no one thinks he is better than another". }\end{array}$ \\
\hline
\end{tabular}

Source: author's compilation based on the research results. 
In the end of the interview, we asked the organizations' leaders which management functions, in their opinion are the most important: planning, organizing, coordination, motivation and control. It was expected that the leaders will emphasize their balances, as one function fulfilled without another cannot enable a well working management mechanism. However, as much as three fourths of the respondents emphasized the importance of control. A part of the leaders explained that having enabled employees, delegated the decision making to them, the final result and potential negative consequences remain the responsibility of a leader. Control was comprehended as drawing limitations. However, other respondents understood control as restraints, surveillance and a hedge that the employees with work what and how the leader thinks it is necessary. In other words, a quarter of the questioned, in spite of noticing that directivity works less effectively in the modern organizations, cannot change their attitude to the everyday work of a leader.

We also asked the leaders to indicate what is important in organizing the realization of assignments. The answers received practically reflected the results obtained earlier. For example, the respondents said that ,leadership must now be more human oriented: the leader must support and consult the employees instead of requiring and demonstrating his authority“", „a leader must be oriented to the collective success, although [it is] very difficult at the moment. One always wants to take the merits for the result. Leaders put in a lot of work. However, employees also put in a lot [of work]".

The last question of the interview was of a closed type. We asked the leaders to indicate what style of leadership: directive, democratic, liberal, transactional, transformational, situational, collaborative, serving, developing or supportive - allows to achieve highest results and which of these is mostly applied by the leaders of the represented organization. The respondents could choose one to three options. The majority of the leaders chose „collaborative“ (34 individuals out of 48), also, „supportive“ (28 individuals), „developing“ (21 individual), „situational“ (20 individuals), „democratic“ (15 individuals) and „liberal“ (12 individuals). „Directive“, „transactional“, ,transformational“" and „,serving“ were not chosen at all. It can be thought that although we explained the leaders every term, some of them were unacceptable due to a language factor and some sort of emotional load. Transactional and transformational - these words are not used anywhere when speaking in Lithuanian, except for the specialty professional language. In addition, the word „transformational“ relates to some sort of instability, insecurity, change, i.e. has a negative meaning when speaking of a person. The same could be said about „serving“" and „directive“.

Speaking about the leadership style in their work, the leaders emphasized that they are attempting to apply collaboration and adapt to the situation more and more.

\section{Model of a modern leader characteristics}

Generalizing the results of the research, we prepared a model of modern leader characteristics required in contemporary organization (Fig. 1). 


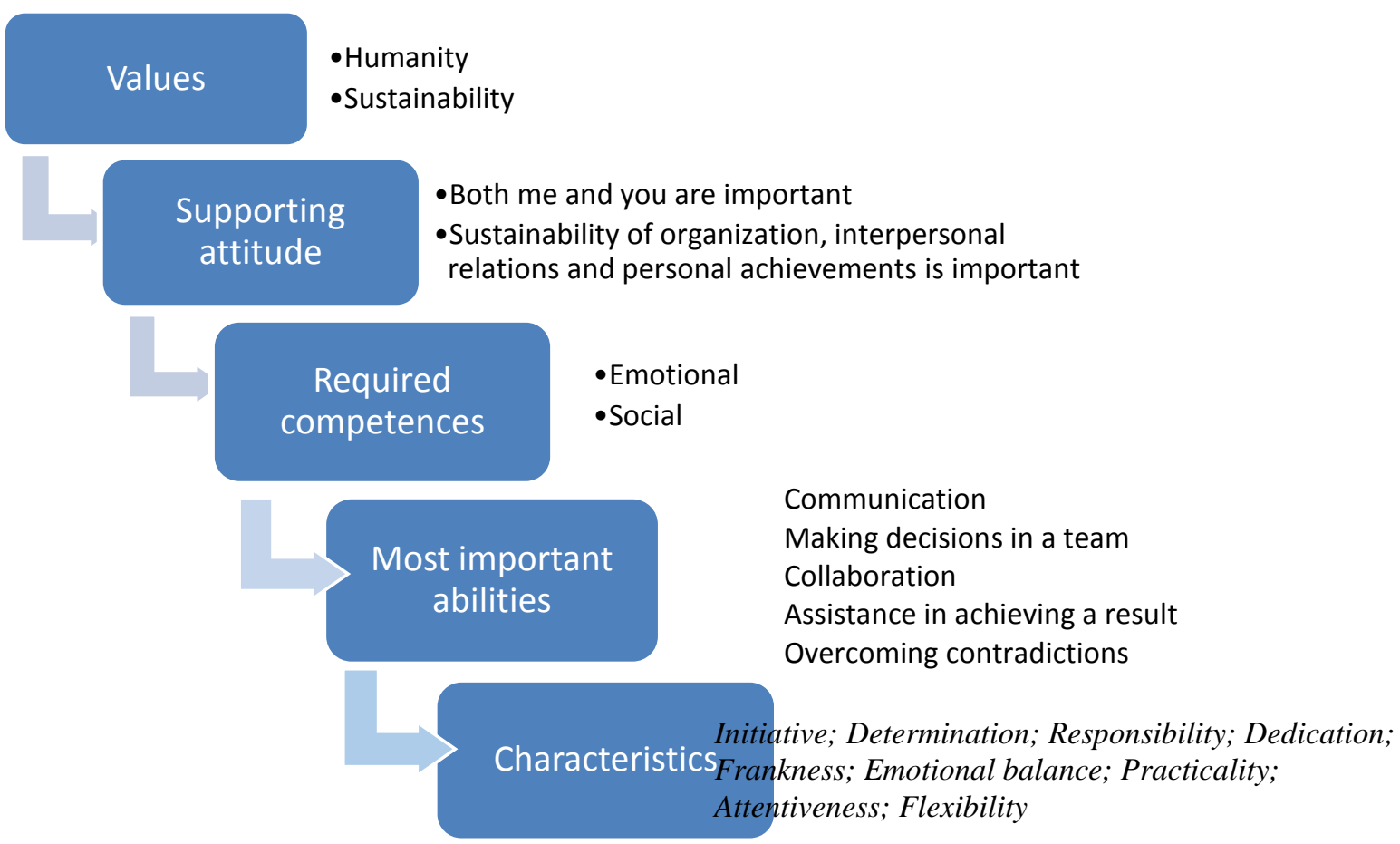

Figure 1. Model of leader characteristics required in contemporary organization Source: own compilation.

This model states that leader's abilities and competences are two reciprocally related variables that are directly influenced by the individual's professional characteristics and attitudes based on his personal values. This model is based on empirical insights, which allows using it as a guideline in developing leaders ' abilities and competences and specialists' skills of leadership. Research shows, that only leader having specific values, attitudes, competencies, abilities and professional characteristics is able to overcome contemporary managerial challenges in nowadays organizations.

\section{Discussion and conclusions}

Comparing the results of theoretical analysis and empirical research, parallels are seen. The researches of organizations emphasize that modern organizations cannot manage without a new attitude to manager's work. A manager must also be a leader these days. What is more, he must be a leader that is able to enable employees, motivate them to work and rally for collaboration. Scholars state that these strivings require the leader to possess high managerial competences based on high emotional and social intellect. The leaders of 48 empirically examined organizations from Lithuania also emphasized the importance of leaders' ability to collaborate, and potency to work in team because relations with other people are becoming much more important for successful business than 10 years ago. Thus, no gap between management theory and attitudes of survey participants was discovered.

The research allowed us to develop the model of leader's values, attitudes, competences, abilities and professional characteristics required in contemporary organization. This model states that leader's values, competences, abilities and professional characteristics are reciprocally related variables, and only coherence of all these variables could lead to management-in-organization success. Furthermore, the research enabled us to define the most important leader's characteristics in contemporary organization. These characteristics are: 
initiative and activity, determination, attention to employees' needs, responsibility, dedication to the work, frankness, emotional balance, practicality, attentiveness and ability to listen, and flexibility. Also five general abilities and competences does a modern leader need in order for his company to be successful: ability to communicate, ability to make decisions in a team, ability to collaborate, ability to help the employees to achieve a result, and ability to overcome various contradictions.

In addition, we found out that nowadays leaders' high social competence should be understood as relevant. However, a particular group of academicians and practitioners held this relevant at all times. It seems that the biggest difference, when comparing periods of time is the proliferation of these attitudes. Therefore, the transformation from production economics (it can be expressed by a phrase "goal justifies means") to knowledge economics (it can be illustrated by a slogan "I know, it means I can") and finally to feeling economics (when an attitude that "what we are doing must no harm anyone and anything" settles) takes place invisibly but with determination. Discrepancy of these attitudes, different mental maturity in organizations and societies that are organized by the tools of public administration are exactly what, in our opinion, influences and will determine in the future the biggest difficulties and disagreements when striving for development and sustainability. It will require higher attention from the leaders of strategic and political level in organizations.

For the end, some limitations of a research methodology should be admitted. Our questions were given only to the leaders of a highest level at organization hierarchy, which could influence twofold aberrations in the results: a) only the opinion, i.e. beliefs and attitudes on the required modern managerial competences was expressed. It remains unknown how they unfold in practice; b) we cannot know how the discussed questions are seen by lower hierarchical level leaders, who actually lead particular employee groups. Nevertheless, given model of leader characteristics could show the nature and complexity of managerial competences, and research insights could serve as guide for managers' education.

\section{References}

Bahreinian, M., Ali, M., Soltani, F. (2012), The relationship between personality type and leadership style of managers: a case study, Mustang Journal of Business \& Ethics, Edmond, Vol. 3, pp. 94-111, ISSN 1949-172.

Belak, J., Duh, M. (2012), Integral Management: Key Success Factors in the MER Model, Acta Polytechnica Hungarica, Vol.9, No.3.

Bhatti, Z. A. et al. (2012), Leadership Styles and Behaviors in Institutional Context, Interdisciplinary journal of contemporary research in business, Vol. 4, No. 2, pp. 744762, ISSN 2073-7122.

Cherniss, C. (2010), Emotional Intelligence: Toward Clarification of a Concept, Industrial and Organizational Psychology, 3, pp. 110-126, ISSN 1754-9426/10.

DeRue, D. S., Barnes, CH. M., Morgeson, F. P. (2010), Understanding the motivational Contingencies of Team Leadership, Small Group Research, Vol. 41, No. 5, pp. 621651.

Diska, V. (2009), Vadovas - lyderis ar administratorius. Ar egzistuoja pusiausvyra? Vadovas: verslo vadyba. - Vilnius, „Pačiolis “, Nr. 10 (155), pp. 15-19, ISSN 2029-0861.

Drodge, E. N. and Murphy, S. A. (2002), Interrogating Emotions in Police Leadership Human Resource Development Review, Vol. 1(4), pp.420-438.

Drygina, Y. et al. (2014), Goal as a basic component of management discourse and language peculiarities of its representation, Journal of Language and Literature, Vol. 5. No. 4.

Gordon, J, Rey, O., Siewiorek, A., Vivitson, M., von Reis, S. (2012), KeyCoNet 2012 Literature Review: Key competence development in school education in Europe. 
Goulding, A., Walton, G., Stephens, D. (2012), The Importance of Political and Strategic Skills for UK Library Leaders, Australian Library Journal, Vol. 61, Iss. 2, pp. 105-118.

Grant, A. M. (2012), Leading with meaning: beneficiary contact, prosocial impact, and the performance effects of transformational leadership, Academy of Management Journal, New York, Vol. 55, No. 2, pp. 458-476, ISSN 1948-0989.

Greenleaf, R. K. (1996), On becoming a servant leader, San Francisco: Jossey-Bass.

Guillen, L, Florent-Treacy, E. (2011), Emotional Intelligenc and Leadership Effectiveness: The Mediating Influenace of Collaborative Behaviors, Journal of Organizational Behavior.

Iqbal, J. (2012), Leadership styles: identifying approaches and dimensions of leaders, Interdisciplinary journal of contemporary research in business, Vol. 4, No. 3, pp. 641659, ISSN 2073-7122.

Izdonaitè-Medziunienè, I., Medziunas, R. (2008), Cooperative social competence development: aspect of tourism managers in Lithuanina higher education, IX International Scientific Conference: Social \& Economic Challenges for Labour Market Proceedings, pp. 28-34.

Jinadasa, D. K., Perera, H. S. C., Samarasinghe, G. D. (2011), Succsess Factors Leading to Business Growth of Micro Level Apparel Manufactures in Gampaha District, Proceedings of the 8th International Conference on Business Management, Vol. 8.

Jones, D. (2011), Servant Leadership's impact on profit, employee satisfaction, and empowerment within the frame work of a participative culture in business, Allied Academies International Conference = Academy for Studies in Business, Las Vegas, Nevada, Vol. 3, No. 2, pp. 9-12, ISSN 2150-5136.

Keast, R. ir Mandell, M. (2011), The Collaborative Push: Pushing Beyond Rhetoric and Gaining Evidence, In 15th Annual Conference of the International Research Society for Public Management, Queensland University of Technology.

Kiaunytė, A., Večkienė, N. P. (2011), Socialinių darbuotojų, patiriančių pokyčius profesinėje veikloje, poreikia paramai: supervizijos perspektyva, Sveikatos ekonomika ir vadyba: sveikatos mokslai, Vol. 21, No. 7, pp. 207-215, ISSN $1392-6373$.

Laužikas, M., Mokšeckienè, R. (2013), The role of creativity in sustainable business, Entrepreneurship and Sustainability Issues, Vol. 1, No. 1, pp. 10-22.

Linley, A. at. al. (2009), Strength Coaching with Leaders, International Coaching Psychology Review: The British Psychological Society, Vol. 4, No. 1, pp. 20-31, ISSN 1750-2764.

Litvaj, I. Poniščiaková, O. (2014), Entrepreneurship and quality management, Entrepreneurship and Sustainability Issues 1(4), pp. 204-209, DOI: http://dx.doi.org/10.9770/jesi.2014.1.4(2).

Marquis, B. L., Huston, C. J. (2009), Leadership Roles and Management Functions in Nursing, Theory and Application, Lippincot, Williams, Wilkins, Philadelphia.

Misiukonis, T. (2012), Asmeninio ugdymo vadovas, Vilnius: Vaga.

Naqvi, S. A. H. et all. (2011), Impact of Supportive Leadership and Organizational Learning Culture as A Moderator on The Relationship of Psychological Empowerment and Organizational Commitment, Australian Journal of Business \& Management Research, Vol. 1, No. 8, pp. 65-76, ISSN 1839 - 0846.

Neale, S., Spencer-Arnell, S., Wilson, L. (2010), Emocinis intelektas ir ugdymas, Vilnius: Verslo žinios, $282 \mathrm{p}$.

Niyazova, G. (2014), Language and power: interaction and interdependence, Journal of Language and Literature, 5(4).

Quatro, S. A., Waldman, D. A., Galvin, B. M. (2007), Developing holistic leaders: Four domains for leadership development and practice, Human Resource Management Review, Vol. 17, Iss. 4, pp. 427-441. 
Raišienè, A. G. (2014), Šiuolaikinių organizacijų veiksmingos vadybos gairès = Management guidance to the effective contemporary organization, In: Raišienè A.G. (ed.) Veiksmingos vadybos gairès: teorinès ižvalgos ir Lietuvos orgaizacijų atvejai $=$ Efective Management Guidelines: Theoretical Insights and Cases from Lithuania's Organizations, Mykolas Romeris University, p. 429.

Skaržauskienè, A., Paražinskaitė, G. (2010), Lietuvos įmonių vadovų intelekto kompetencijų raiška, Socialiniu mokslu studijos, 1(5), pp. 41-61, ISSN 2029-2236.

Stys,Y., Brown, S. L. (2004), A review of the emotional intelligence literature and implications for corrections, Research Branch, Correctional service of Canada, NR-150, pp. 41-57.

Thompson, K. N. (2010), Servant Leadership: an effective model for Project management: doctor disertation: philosophy, Minneapolis: Capella University, 135 p.

Vizgirdaitè, J. (2011), Meaning of Collaboration: from Different Social Contexts to Common Understanding, Socialiniai mokslai, Kaunas: Kauno technologojos universitetas, Nr. 4(74), pp. 70-83, ISSN 1392-0758.

Wijepala, U. S., Wijesundara, T. (2011), The Entrepreneurial Management Leadership And Organizational Success - A Socio-Management Study: The Case Of Lakshmi Apparel Garment Factory, Maharagama, Sri Lanka, Proceedings of the 8th International Conference on Business Management, Vol. 8.

Zakharchyn, H., Lyubomudrowa, N. (2014), Humanization of work as a factor of employees' motivation, Actual Problems of Economics, Issue 7(157), pp. 343-349.

Žukauskaitè, I. (2010), Naujų darbuotojų socializaciją organizacijoje prognozuojantys veiksniai, Organizaciju vadyba: sisteminiai tyrimai, Nr. 56, pp. 133-150, ISSN 13921142 . 